\title{
Effectiveness of heparin versus $0.9 \%$ saline solution in maintaining the permeability of central venous catheters: a systematic review*
}

\author{
Eficácia da heparina e soro fisiológico para manter a permeabilidade \\ dos cateteres venosos centrais: revisão sistemática \\ Efectividad de la heparina y el suero fisiológico para mantener la \\ permeabilidad de los catéteres venosos centrales: revisión sistemática
}

Eduardo José Ferreira dos Santos ${ }^{1}$, Maria Madalena Jesus Cunha Nunes ${ }^{2}$, Daniela Filipa Batista Cardoso ${ }^{1}$, João Luís Alves Apóstolo ${ }^{1}$, Paulo Joaquim Pina Queirós ${ }^{1}$, Manuel Alves Rodrigues ${ }^{1}$

* Extracted from the dissertation "Eficácia da heparina e do soro fisiológico para manter a permeabilidade dos cateteres venosos centrais em adultos," Escola Superior de Saúde de Viseu, 2015.

${ }^{1}$ Escola Superior de Enfermagem de Coimbra, Unidade de Investigação em Ciências da Saúde, Coimbra, Portugal.

${ }^{2}$ Instituto Politécnico de Viseu, Centro de Estudos em Educação, Tecnologias e Saúde, Viseu, Portugal.

\section{ABSTRACT}

Objective: Determining which is the most effective solution (heparin flush compared to $0.9 \%$ saline flush) for reducing the risk of occlusions in central venous catheters (CVC) in adults. Method: The systematic review followed the principles proposed by the Cochrane Handbook; critical analysis, extraction and synthesis of data were performed by two independent researchers; statistical analysis was performed using the RevMan program 5.2.8. Results: Eight randomized controlled trials and one cohort study were included and the results of the meta-analysis showed no difference $(\mathrm{RR}=0.68,95 \% \mathrm{CI}=0.41-1.10$; $p=0.12$ ). Analysis by subgroups showed that there was no difference in fully deployed CVC (RR=1.09, CI 95\%=0.53-2.22; $p=0.82)$; Multi-Lumen CVC showed beneficial effects in the heparin group ( $\mathrm{RR}=0.53$, CI 95\%=0.29-0.95; $p=0.03)$; in Double-Lumen CVC for hemodialysis $(\mathrm{RR}=1.18, \mathrm{CI} 95 \%=0.08-17.82 ; p=0.90)$ and Peripherally inserted CVC (RR=0.14, CI 95\%=0.01-2.60; $p=0.19$ ) also showed no difference. Conclusion: Saline solution is sufficient for maintaining patency of the central venous catheter, preventing the risks associated with heparin administration.

\section{DESCRIPTORS}

Catheterization, Central Venous; Heparin; Sodium Chloride; Central Venous Catheters; Review. 


\section{INTRODUCTION}

Inclusion of a Central Venous Catheter (CVC) is often necessary when the clinical condition of the patient requires monitoring of some hemodynamic parameters, fluid therapy, administration of drugs, blood products, parenteral nutrition, and dialysis, among other procedures ${ }^{(1)}$. Although on the one hand its use has enabled therapeutic advances, it has also led to the origin of various associated risks, of which infection and catheter obstruction ${ }^{(1-4)}$ can be highlighted; factors contributing to an increase of hospital internalizations, morbidity and hospitalization costs ${ }^{(4)}$.

For these reasons, CVC handling, maintenance and optimization is complicit to the predominant value of care, where nurses must gather a body of knowledge and skills to ensure proper handling of the $\mathrm{CVC}^{(5)}$.

Nevertheless, despite the existence of several international recommendations and guidelines related to this subject, doubts still persist regarding which should be used when we discuss the recommended solution to maintaining CVC patency, since there are several practices in use in the clinical setting (saline, heparin, sodium citrate, and other chemical solutions) $)^{(6)}$.

Historically, heparin solution has been the most commonly used method to maintain catheter patency, dating back to the $1970 \mathrm{~s}^{(1)}$. However, this practice seems to have concealed its negative effects ${ }^{(1,3)}$, of which we can highlight the iatrogenic effects of the drug itself, such as thrombocytopenia.

Heparin is an anticoagulant that acts at the level of the coagulation cascade and inhibits platelet aggregation ${ }^{(1)}$, contributing to the occurrence of thrombocytopenia and bleeding, even when used in small quantities in CVC optimization (washing/flushing) ${ }^{(1,7)}$. It is administered daily in hospitals to approximately 12 million patients, for whom there are documented cases of morbidity and mortality associated with severe complications ${ }^{(7)}$. Thrombocytopenia associated with the administration of heparin is developed in about $1-5 \%$ of the exposed population, and it is recognized that intravenous exposure to heparin alone is a predictive factor for developing thrombocytopenia ${ }^{(7-8)}$.

From a macro perspective, indiscriminate use of heparin for CVC also has negative economic and social consequences when compared with the use of saline solution, because the obstruction of CVC implies an interruption of therapeutic treatments and an increase in the risks associated with catheterization for the patient, which becomes more important in the aspect of quality healthcare ${ }^{(3)}$.

We cannot help but reflect on the different focuses that are necessary in this practice of nursing: thrombocytopenia is related to the frequent use of heparin; thrombocytopenia risk exists even when the exposure is minimal; heparin is found in various concentrations and formulations, increasing the risk of error in dilution preparation; and several studies have suggested that heparin is related to medication errors ${ }^{(1,3)}$.

On the other hand, some studies suggest that saline flush is cost-effective, adequate and also has the benefit of not having the adverse effects of heparin and not having several presentations nor preparation required at different concentrations $^{(2,9-14)}$. In this context, some published studies have reported that most nurses use only saline solutions, enhancing the fact that CVC flushing practices vary widely, and are currently inconsistent ${ }^{(15)}$.

This fact is even more significant because most existing guidelines for maintaining $\mathrm{CVC}$ are not based on evidence and do not identify any recommendations that promote flushing with only saline solution ${ }^{(16)}$. When considering these gaps, this issue was identified as a research priority that could indicate significant benefits for the reduction of adverse events ${ }^{(5)}$. In this context, it is clear that there exists the need to investigate the decision of using heparin or $0.9 \%$ sodium chloride in CVC permeability/patency; this led us to develop the research question: What is the most effective flush to reduce central venous catheter occlusion rates in adults? In order to set the limits of the research, the objective was defined as: Determining the effectiveness of heparinized flush solutions compared to $0.9 \%$ saline flush in the permeability of central venous catheters in adults.

\section{METHOD}

To carry out this systematic literature review and to respond to the previously formulated research question, we adopted the principles proposed by the Cochrane Handbook ${ }^{(17)}$ and the research results were reported according to the Preferred Reporting Items for Systematic Reviews and Meta-Analysis (PRISMA) statement ${ }^{(18-19)}$.

It is worth mentioning that prior to the start of the empirical phase of the established research process, it had been approved by Ethics Committee of the Escola Superior de Saúde de Viseu (Number 35/2013). The lead author and co-authors established the protocol for this review which has not been published.

The location and selection of studies were based on a process consisting of three stages:

1) An initial naturalistic research limited to MEDLINE and CINAHL was performed, followed by an analysis of the words in the titles, abstracts and indexing terms used to describe the studies. Then we decided to confirm if the preliminary terms constituted $\mathrm{MeSH}$ descriptors via the website http://www.ncbi.nlm.nih.gov/mesh, obtaining positive response for: \#1 MeSH descriptor "Catheterization, central venous" (explode all trees); \#2 $\mathrm{MeSH}$ descriptor "Catheterization" (explode all trees); \#3 MeSH descriptor "Catheters" (explode all trees); \#4 MeSH descriptor "Heparin" (explode all trees); \#5 $\mathrm{MeSH}$ descriptor "Sodium chloride" (explode all trees).

2) The second research was carried out between December 2013 and February 2014, replicated in May 2015, and included electronic research in the following databases: CINAHL Plus with Full Text, MedicLatina, MEDLINE with Full Text, Cochrane Database of Systematic Reviews, Cochrane Central Register of Controlled Trials, Nursing \& Allied Health Collection: Comprehensive (via EBSCO); Elsevier - Science Direct (via bon - Online Knowledge Library); JBI Library; Scopus; Scielo - Scientific Electronic Library Online; Academic Google (for extracting full text articles that could not be 
obtained by other means) - through Boolean combination of all identified keywords: \#6 [\#1 OR \#2 OR \#3 AND \#4 AND \#5] (subject); \#7 [central venous catheter* OR catheter*AND heparin OR sodium chloride] (title and abstract).

3) Finally, the list of references of all identified studies was analyzed to extract additional studies.

Inclusion criteria:

Participants: patients with central venous catheters (of any kind). Adults aged 18 or older in the hospital and/or clinical setting. Exclusion criteria included patients with coagulation disorders, hemorrhagic disease, family history of heparin allergy, who had prolonged oral or systemic treatment with anticoagulant drugs; and patients indicated for abdominal or orthopedic surgery.

Intervention: studies comparing the effectiveness of different washing solutions (flush) to maintain the permeability of different types of central venous catheters;

Comparisons: all heparinized solutions described in the literature vs. $0.9 \%$ saline solution;

Outcome: $C V C$ occlusion rate (defined as inability to infuse fluid through the catheter due to an obstruction);

Design: only experimental studies were included, including randomized controlled trials, non-randomized controlled studies; and quasi-experimental studies, including before-and-after studies and cohort studies; studies published in English, Spanish and Portuguese; published from January 2000 to May 2015.

A critical appraisal was done prior to inclusion in the review by two reviewers with experience in the isolated method, and neither had knowledge of test results at any time during this process ${ }^{(17)}$.

The tools for critical appraisal were: Grid for critical evaluation of an article describing a prospective, randomized and controlled clinical study of the Centro de Estudos de Medicina Baseada na Evidência da Faculdade de Medicina de Lisboa, Portugal, which only considers high-quality studies which met a score equal to or higher than $75 \%(20)$ to assess RCT (Randomized Clinical Trial); and JBI Critical Appraisal Checklist for Cohort and Case-Control Studies that according to the consensus of the authors are considered quality studies that obtain up to two negative responses ${ }^{(21-22)}$ to assess cohort studies. In the absence of consensus among the reviewers, disagreements that emerged were resolved through discussion with the inclusion of a third reviewer ${ }^{(22)}$.

Data were extracted from the included studies in the corpus by two isolated reviewers using the instrument The Joanna Briggs Institute data extraction form for systematic review of experimental/observational studies, with disagreements being resolved by discussion or a third reviewer. The authors were contacted for information or missing data that needed clarification ${ }^{(22)}$.

In the process of synthesis, quantitative data were grouped and meta-analysis was performed with the use of Cochrane Collaboration's Review Manager software (RevMan 5.2.8; <http://ims.cochrane.org/RevMan>). All results were subjected to dual input data.
The results were expressed in relative risk (RR) with $95 \%$ confidence intervals, as referring to dichotomous data (categorical data).

The $Q$ test and $I^{2}$ were calculated to verify the existence of heterogeneity among studies, where a $I^{2}$ value close to $0 \%$ indicates no heterogeneity, close to $25 \%$ indicates low heterogeneity, close to $50 \%$ indicates moderate heterogeneity, and close to $75 \%$ indicates high heterogeneity among the studies ${ }^{(23)}$. Due to the heterogeneity found, analyses were performed with the use of the random effects model ${ }^{(21-23)}$, which implies that the effect of interest is not the same across all the studies, assuming the existence of a certain degree of clinical heterogeneity that is not liable to be controlled ${ }^{(23)}$.

Levels of evidence and grades of recommendation were established based on the classification currently used ${ }^{(24)}$.

Effectiveness comparison of heparinized flush solutions with $0.9 \%$ saline flush on CVC permeability was performed through three analyses (meta-analysis by subgroups): by CVC type, by design of the included studies and by their setting (context).

\section{RESULTS}

Of all the studies identified by the method explained in the previous section, we noted that the first selected sample comprised 4,649 studies.

Two independent researchers excluded 292 studies based on the inclusion criteria by reading the titles and 1,854 by reading the abstract.

After analyzing the full text of the articles $(n=36)$, 28 studies were excluded, resulting in a corpus consisting of eight studies. Bibliography analysis of identified reference articles also allowed the inclusion of another study, thus nine studies were considered for critical appraisal: eight $\operatorname{RCT}^{(2,6,9,11-14,16)}$ and one cohort study ${ }^{(10)}$.

The entire process of study corpus selection can be summarized by the following flow chart (shown in Figure 1).

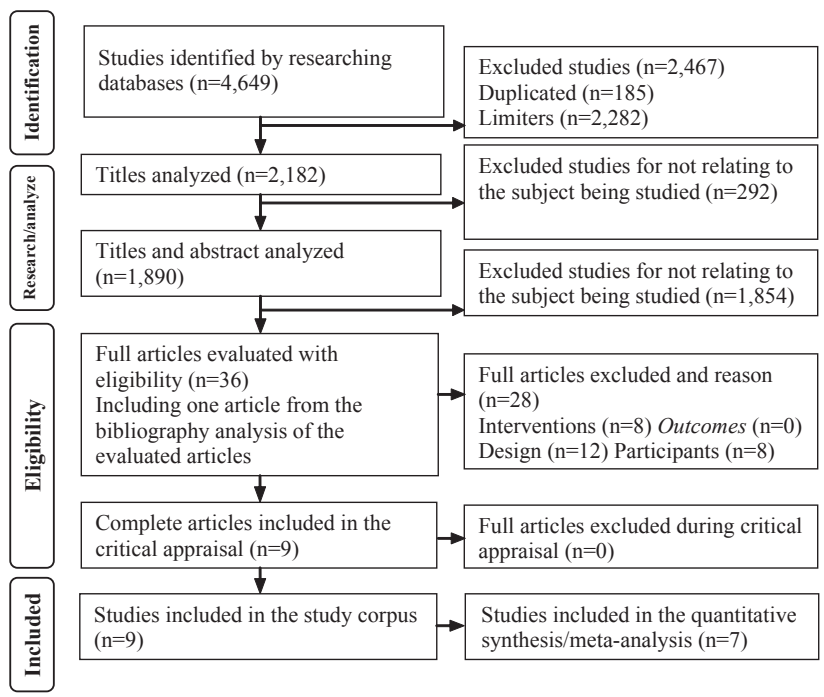

Figure 1 - Representative flowchart of study corpus refinement stages - Viseu, Portugal, 2015.

For a detailed explanation of the evaluation of the methodological quality of the studies, we present Figure 2 
based on the "Cochrane Collaboration tool for Assessing risk of bias"(17).

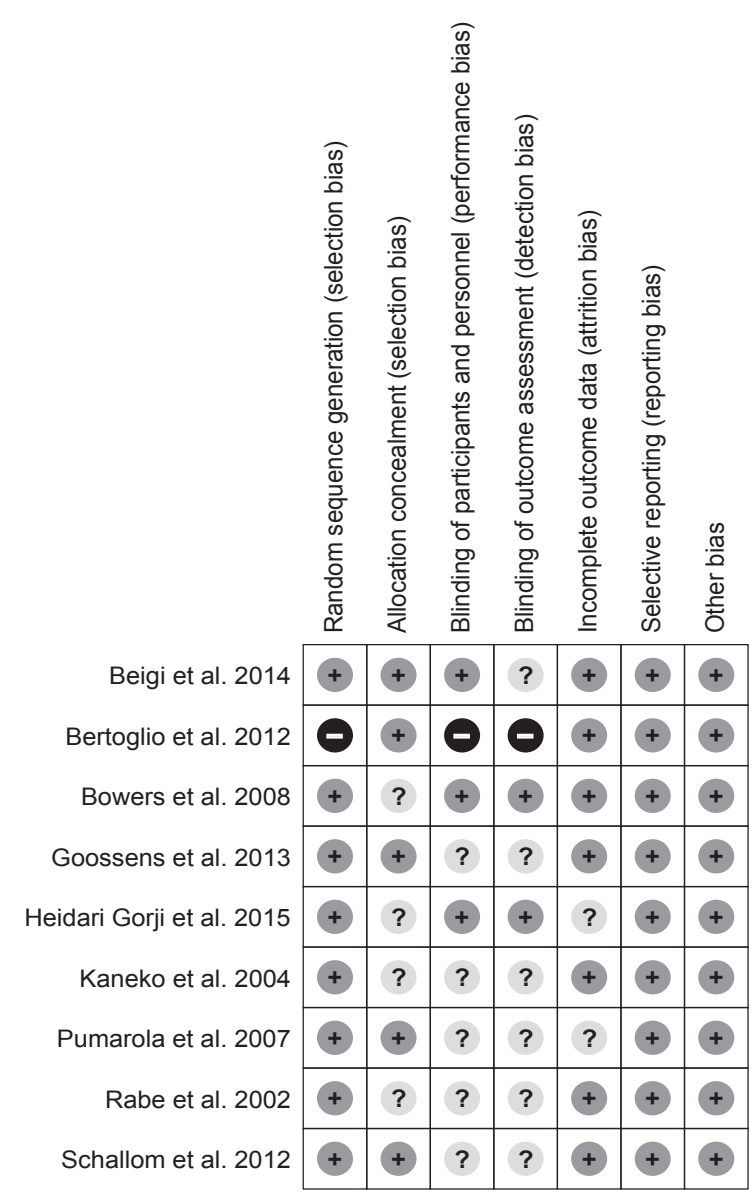

Justification of the scores

+ Risk of bias unlikely to alter the results

? Risk of bias raises some doubts about the results

- Risk of bias seriously weakens the reliability of the results

Figure 2 - Summary of risk of bias according to the critical appraisal of the reviewers - Viseu, Portugal, 2015.

Below we present a summary of the most important aspects of the characteristics of the studies included in the study corpus, which were grouped and organized into an "evidence table" (see Chart 1).

Chart 1 - Study corpus characteristics of the included studies Viseu, Portugal, 2015.

\begin{tabular}{|c|c|c|c|c|}
\hline Study & $\begin{array}{c}\text { CVC } \\
\text { specificities }\end{array}$ & $\begin{array}{l}\text { Evaluation } \\
\text { of catheter } \\
\text { permeability }\end{array}$ & $\begin{array}{l}\text { Catheters } \\
\text { duration/ } \\
\text { time }\end{array}$ & $\begin{array}{c}\text { Type of } \\
\text { infusion } \\
\text { (medicinal } \\
\text { products } \\
\text { and } \\
\text { solutions) }\end{array}$ \\
\hline $\begin{array}{l}\text { Rabe } \\
\text { et al. } .^{(6)}\end{array}$ & $\begin{array}{c}\text { Triple- } \\
\text { Lumen CVC }\end{array}$ & Every 2 days & 20 days & $\begin{array}{l}\text { Not re- } \\
\text { ported }\end{array}$ \\
\hline $\begin{array}{l}\text { Kaneko } \\
\text { et al. }{ }^{(9)}\end{array}$ & $\begin{array}{c}\text { Double- } \\
\text { Lumen CVC } \\
\text { with } \\
\text { urokinase }\end{array}$ & $\begin{array}{c}\text { After each } \\
\text { hemodialysis } \\
\text { session }\end{array}$ & $\begin{array}{l}\text { Not } \\
\text { reported }\end{array}$ & $\begin{array}{l}\text { Hemodi- } \\
\text { alysis }\end{array}$ \\
\hline
\end{tabular}

continued...

\begin{tabular}{|c|c|c|c|c|}
\hline Study & $\begin{array}{c}\text { CVC } \\
\text { specificities }\end{array}$ & $\begin{array}{l}\text { Evaluation } \\
\text { of catheter } \\
\text { permeability }\end{array}$ & $\begin{array}{l}\text { Catheters } \\
\text { duration/ } \\
\text { time }\end{array}$ & 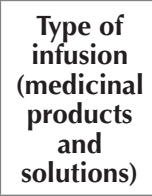 \\
\hline $\begin{array}{l}\text { Pumarola } \\
\text { et al. } .^{(2)}\end{array}$ & $\begin{array}{c}\text { Triple- } \\
\text { Lumen CVC }\end{array}$ & $\begin{array}{l}\text { At } 24 \text { and } 72 \\
\text { hours, and } \\
\text { at hospital } \\
\text { discharge }\end{array}$ & $\begin{array}{c}\text { Until } \\
\text { catheter } \\
\text { occlusion } \\
\text { or medical } \\
\text { discharge }\end{array}$ & $\begin{array}{l}\text { Not re- } \\
\text { ported }\end{array}$ \\
\hline $\begin{array}{l}\text { Bertoglio } \\
\text { et al. }{ }^{(10)}\end{array}$ & $\begin{array}{l}\text { Fully } \\
\text { deployed } \\
\text { CVC }\end{array}$ & $\begin{array}{l}\text { Monthly } \\
\text { evaluation } \\
\text { or at the } \\
\text { end of each } \\
\text { therapeutic } \\
\text { administration }\end{array}$ & $\begin{array}{l}\text { Minimum } \\
\text { of } 12 \\
\text { months }\end{array}$ & $\begin{array}{l}\text { Chemo- } \\
\text { therapy; } \\
\text { Parenteral } \\
\text { nutrition }\end{array}$ \\
\hline $\begin{array}{l}\text { Schallom } \\
\text { et al. (11) }\end{array}$ & $\begin{array}{c}\text { Multiple- } \\
\text { Lumen CVC }\end{array}$ & $\begin{array}{l}\text { Every } 8 \text { hours, } \\
\text { intravenous } \\
\text { without } \\
\text { continuous } \\
\text { infusion }\end{array}$ & 22 days & $\begin{array}{l}\text { Intermittent } \\
\text { and non- } \\
\text { specific } \\
\text { continuous } \\
\text { infusions }\end{array}$ \\
\hline $\begin{array}{l}\text { Goossens } \\
\text { et al. } .^{(12)}\end{array}$ & $\begin{array}{l}\text { Fully } \\
\text { deployed } \\
\text { CVC }\end{array}$ & $\begin{array}{l}\text { Before remov- } \\
\text { ing the needle } \\
\text { from the } \\
\text { CVC; before } \\
\text { and after } \\
\text { each therapy } \\
\text { administration } \\
\text { and every } 8 \\
\text { weeks if not } \\
\text { in use }\end{array}$ & 180 days & $\begin{array}{l}\text { Intermittent } \\
\text { and non- } \\
\text { specific } \\
\text { continuous } \\
\text { infusions; } \\
\text { Blood de- } \\
\text { rivatives; } \\
\text { Parenteral } \\
\text { nutrition }\end{array}$ \\
\hline $\begin{array}{l}\text { Bowers } \\
\text { et al. }{ }^{(13)}\end{array}$ & $\begin{array}{l}\text { Peripher- } \\
\text { ally inserted } \\
\text { CVC }\end{array}$ & $\begin{array}{l}\text { According } \\
\text { to medical } \\
\text { prescription, } \\
\text { at every } 12 \text { or } \\
24 \text { hours }\end{array}$ & $\begin{array}{l}\text { Until } \\
\text { catheter } \\
\text { occlusion } \\
\text { or medical } \\
\text { discharge }\end{array}$ & $\begin{array}{c}\text { Non- } \\
\text { specific } \\
\text { intravenous } \\
\text { therapy }\end{array}$ \\
\hline $\begin{array}{l}\text { Heidari } \\
\text { Gorji } \\
\text { et al. }{ }^{(16)}\end{array}$ & CVC & $\begin{array}{l}\text { Every } 8 \text { hours, } \\
\text { intravenous } \\
\text { without } \\
\text { continuous } \\
\text { infusion }\end{array}$ & 21 days & $\begin{array}{l}\text { Non- } \\
\text { specific } \\
\text { intravenous } \\
\text { therapy }\end{array}$ \\
\hline $\begin{array}{l}\text { Beigi } \\
\text { et al. }{ }^{(14)}\end{array}$ & $\begin{array}{c}\text { Double- } \\
\text { Lumen CVC }\end{array}$ & $\begin{array}{c}\text { At CVC } \\
\text { placement, } \\
\text { at } 12 \text { and } 24 \\
\text { hours }\end{array}$ & 1 day & $\begin{array}{l}\text { Hemodi- } \\
\text { alysis }\end{array}$ \\
\hline
\end{tabular}

We also present a summary of the most important aspects of the main results from analyzing the selected studies (see Chart 2).

\section{Summary of QUANTITATIVe data - Meta-Analysis}

Analyzing the results of the meta-analysis and the respective forest plot (as shown in Figure 3), we can infer that there is no statistical significance, because the combined result of the meta-analysis overlaps the no-effect line.

Nevertheless, we can still point out that there is a beneficial effect in the group using the heparinized solutions as a flush because although there is no statistical significance, there is increased risk of non-permeable CVC in the saline solution group, supported by the value of meta-analytical result $(\mathrm{RR}=0.68$, CI 95\%=0.41-1.10; $p=0.12)$. From the heterogeneity study we can infer that this is statistically significant and it is classified as low $\left(\mathrm{Tau}^{2}=0.03, \chi^{2}=4.41\right.$, $\left.\mathrm{df}=4, p=0.35 ; I^{2}=9 \%\right)$.

For the subgroup of fully deployed CVC, it was found that there are no statistically significant differences 
$(\mathrm{RR}=1.09$, CI 95\%=0.53-2.22; $p=0.82)$. In the subgroup of $\mathrm{CVC}$ with multiple lumens, there was a beneficial effect in the heparin group, which is a statistically significant result $(\mathrm{RR}=0.53$, CI 95\%=0.29-0.95; $p=0.03)$ and without significant heterogeneity among the studies $\left(\mathrm{Tau}^{2}=0.00 ; \chi^{2}=0.70\right.$, $\left.\mathrm{df}=1, p=0.40 ; I^{2}=0 \%\right)$. In the subgroup of double lumen CVC for hemodialysis, a beneficial effect in the saline solution group was verified, although it did not reach statistical significance $(R R=1.18, C I 95 \%=0.08-17.82 ; p=0.90)$. Finally, in relation to the subgroup of peripherally inserted CVC, statistical significance was also not observed $(R R=0.14, C I$ $95 \%=0.01-2.60 ; p=0.19)$. We emphasize that the analysis of the differences between subgroups reveals low heterogeneity $\left(\chi^{2}=3.69, \mathrm{df}=3, p=0.30 ; I^{2}=18.7 \%\right)$.

Chart 2 - Main results of the studies included in the study corpus - Viseu, Portugal, 2015

\begin{tabular}{|c|c|c|c|c|c|c|}
\hline \multirow[b]{2}{*}{$\begin{array}{l}\text { Author/ Year/ } \\
\text { Country }\end{array}$} & \multirow[b]{2}{*}{$\begin{array}{l}\text { Type of study/ } \\
\text { Population }\end{array}$} & \multicolumn{2}{|c|}{ Interventions } & \multirow[b]{2}{*}{ Results/Outcomes } & \multirow[b]{2}{*}{ Conclusions } & \multirow{2}{*}{$\begin{array}{l}\text { Critical } \\
\text { appraisal } \\
\text { of quality }\end{array}$} \\
\hline & & Experimental & Control & & & \\
\hline $\begin{array}{l}\text { Rabe et al. }{ }^{(6)} \\
\text { (Germany) }\end{array}$ & $\begin{array}{l}\mathrm{RCT} / \mathrm{n}=99 \\
\text { Participants in } \\
\text { intensive care }\end{array}$ & $\begin{array}{c}\text { 5000IU of } \\
\text { Heparin/ml Flush }\end{array}$ & $\begin{array}{l}0.9 \% \text { saline } \\
\text { solution Flush } \\
200 \mathrm{mg} / \mathrm{ml} \\
\text { vitamin C } \\
\text { Flush }\end{array}$ & $\begin{array}{l}\text { There was no difference } \\
\text { between the use of } \\
\text { heparin and the SS } \\
(p<0.04 \text {, log-rank test). }\end{array}$ & $\begin{array}{l}\text { Heparin-solutions are } \\
\text { most effective when } \\
\text { compared to saline } \\
\text { solution in maintaining } \\
\text { CVC permeability. }\end{array}$ & $80 \%$ \\
\hline $\begin{array}{l}\text { Kaneko et al. }{ }^{(9)} \\
\text { (Japan) }\end{array}$ & $\begin{array}{l}\mathrm{RCT} / \mathrm{n}=48 \\
\text { Hospitalized } \\
\text { participants }\end{array}$ & $\begin{array}{l}20 \mathrm{ml} \text { of saline } \\
\text { solution Flush }\end{array}$ & $\begin{array}{c}20 \mathrm{ml} \text { of } \\
\text { saline solution } \\
\text { Flush }+ \\
2 \mathrm{ml} \text { of } 1000 \\
\mathrm{IU} / \mathrm{ml} \text { heparin }\end{array}$ & $\begin{array}{l}\text { There was no difference } \\
\text { between the use of } \\
\text { heparin and the SS } \\
(p=0.8599) .\end{array}$ & $\begin{array}{l}\text { Saline solution is } \\
\text { sufficient in maintaining } \\
\text { central catheter } \\
\text { permeability for } \\
\text { hemodialysis. }\end{array}$ & $75 \%$ \\
\hline $\begin{array}{l}\text { Pumarola } \\
\text { et al.(2) } \\
\text { (Spain) }\end{array}$ & $\begin{array}{l}\mathrm{RCT} / \mathrm{n}=95 \\
\text { Participants in } \\
\text { intensive care }\end{array}$ & $\begin{array}{l}0.9 \% \text { saline } \\
\text { solution Flush }\end{array}$ & $\begin{array}{c}100 I U \\
\text { Heparin Flush }\end{array}$ & $\begin{array}{l}\text { There was no difference } \\
\text { between the use } \\
\text { of heparin and SS } \\
(p=0.744) .\end{array}$ & $\begin{array}{c}0.9 \% \text { saline is also } \\
\text { effective compared to } \\
100 \text { IU or } 500 \text { IU heparin } \\
\text { in maintaining CVC } \\
\text { permeability. }\end{array}$ & $85 \%$ \\
\hline $\begin{array}{l}\text { Bertoglio } \\
\text { et al. }{ }^{(10)} \\
\text { (Italy) }\end{array}$ & $\begin{array}{l}\text { Retrospective } \\
\text { cohort study/n } \\
=610 \\
\text { Participants in the } \\
\text { cancer unit }\end{array}$ & $\begin{array}{l}500 \text { IU/ SS } 10 \mathrm{ml} \\
\text { Heparin Flush }\end{array}$ & $\begin{array}{l}10 \mathrm{ml} \text { of } 0.9 \% \\
\text { saline solution } \\
\text { Flush }\end{array}$ & $\begin{array}{c}\text { There was no difference } \\
\text { between the use of } \\
\text { heparin and SS (HR - } 1.2 ; \\
95 \% \mathrm{Cl}: 0.6-2.5 ; \mathrm{p}=0.7) \text {. }\end{array}$ & $\begin{array}{c}\text { Saline solution is as } \\
\text { effective as heparinized } \\
\text { solution in maintaining } \\
\text { patency. }\end{array}$ & 7 points \\
\hline $\begin{array}{l}\text { Schallom } \\
\text { et al. }{ }^{(11)} \\
\text { (USA) }\end{array}$ & $\begin{array}{c}\mathrm{RCT} / \mathrm{n}=709 \\
\text { lumens/n = } 341 \\
\text { Hospitalized } \\
\text { participants }\end{array}$ & $\begin{array}{l}\text { 10IU Heparin/ml } \\
\text { Flush }\end{array}$ & $\begin{array}{l}10 \mathrm{ml} \text { of } 0.9 \% \\
\text { saline solution } \\
\text { Flush }\end{array}$ & $\begin{array}{l}\text { There was no difference } \\
\text { between the use of } \\
\text { heparin and SS }(\mathrm{RR}= \\
1.66,95 \% \mathrm{Cl}=0.86- \\
3.22 ; \mathrm{p}=0.136)\end{array}$ & $\begin{array}{c}\text { Saline solution may be } \\
\text { preferable in maintaining } \\
\text { CVC patency, when } \\
\text { used for a short time, } \\
\text { compared to heparin. }\end{array}$ & $85 \%$ \\
\hline $\begin{array}{l}\text { Goossens } \\
\text { et al. }{ }^{(12)} \\
\text { (Belgium) }\end{array}$ & $\begin{array}{l}\mathrm{RCT} / \mathrm{n}=802 \\
\text { Participants of the } \\
\text { cancer unit }\end{array}$ & $\begin{array}{l}\text { 300IU Heparin } \\
\text { /3ml Flush }\end{array}$ & $\begin{array}{l}10 \mathrm{ml} \text { of } 0.9 \% \\
\text { saline solution } \\
\text { Flush }\end{array}$ & $\begin{array}{c}\text { There was no difference } \\
\text { between the use of } \\
\text { heparin and SS (RR = } \\
0.94,95 \% \mathrm{Cl}=0.67 \%- \\
1.32 \%)\end{array}$ & $\begin{array}{l}\text { Saline is an effective } \\
\text { solution for fully } \\
\text { deployed CVC flush. }\end{array}$ & $85 \%$ \\
\hline $\begin{array}{l}\text { Bowers } \\
\text { et al. }{ }^{(13)}\end{array}$ & $\begin{array}{l}\mathrm{RCT} / \mathrm{n}=102 \\
\text { Hospitalized } \\
\text { participants }\end{array}$ & $\begin{array}{l}100 \mathrm{IU} / \mathrm{ml}(3 \mathrm{ml}) \\
\text { Heparin Flush }\end{array}$ & $\begin{array}{l}10 \mathrm{ml} \text { of } 0.9 \% \\
\text { saline solution } \\
\text { Flush }\end{array}$ & $\begin{array}{c}\text { There was no difference } \\
\text { between the use of } \\
\text { heparin and SS ( } 6 \% \text { rates } \\
\text { of occlusion in SS group). }\end{array}$ & $\begin{array}{l}\text { Saline solution is } \\
\text { sufficient in maintaining } \\
\text { CVC permeability of } \\
\text { peripheral insertions. }\end{array}$ & $80 \%$ \\
\hline $\begin{array}{l}\text { Heidari Gorji } \\
\text { et al. (16) } \\
\text { (Iran) }\end{array}$ & $\begin{array}{c}\mathrm{RCT} / \mathrm{n}=84 \\
\text { Participants in } \\
\text { intensive care }\end{array}$ & $\begin{array}{l}10 \mathrm{IU} / \mathrm{ml}(3 \mathrm{ml}) \\
\text { Heparin Flush }\end{array}$ & $\begin{array}{c}10 \mathrm{ml} \text { of } 0.9 \% \\
\text { saline solution } \\
\text { Flush }\end{array}$ & $\begin{array}{c}\text { There was no difference } \\
\text { between the use } \\
\text { of heparin and SS } \\
(p=0.872) .\end{array}$ & $\begin{array}{l}\text { Saline solution is } \\
\text { recommended in } \\
\text { maintaining CVC } \\
\text { permeability. }\end{array}$ & $85 \%$ \\
\hline $\begin{array}{l}\text { Beigi et al. }{ }^{(14)} \\
\text { (Iran) }\end{array}$ & $\begin{array}{l}\mathrm{RCT} / \mathrm{n}=96 \\
\text { Hospitalized } \\
\text { participants }\end{array}$ & $\begin{array}{c}1000 \text { IU/10 ml SS } \\
\text { Heparin Flush }\end{array}$ & $\begin{array}{l}10 \mathrm{ml} \text { of } 0.9 \% \\
\text { saline solution } \\
\text { Flush }\end{array}$ & $\begin{array}{c}\text { There was no difference } \\
\text { between the use of } \\
\text { heparin and SS (no CVC } \\
\text { occlusions) }\end{array}$ & $\begin{array}{l}\text { Saline is effective } \\
\text { in maintaining CVC } \\
\text { permeability for } \\
\text { hemodialysis. }\end{array}$ & $80 \%$ \\
\hline
\end{tabular}




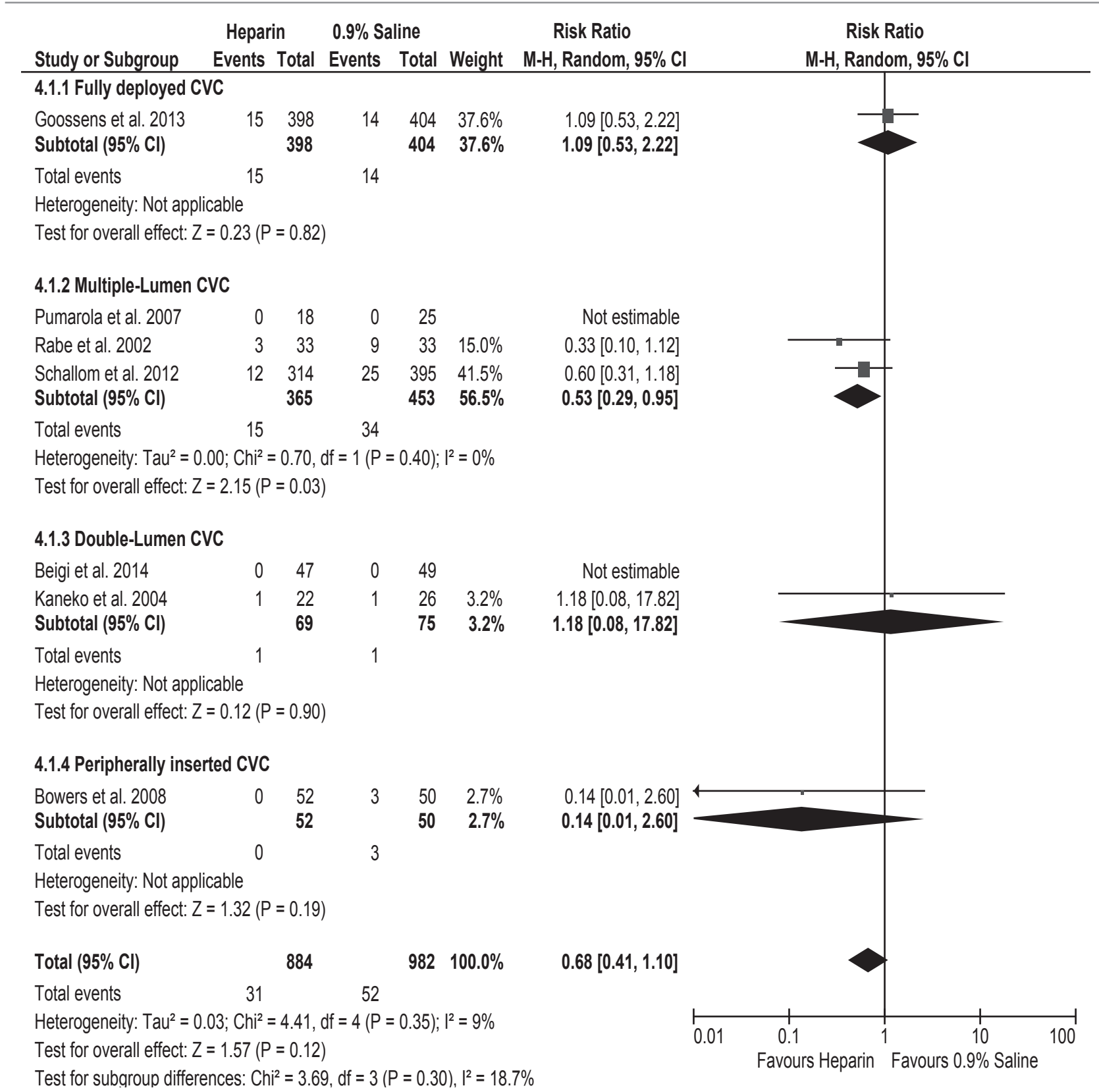

Figure 3 - Forest plot of heparin comparison versus saline solution for CVC permeability from RCT studies for the outcome of nonpermeable CVC for subgroups of CVC types - Viseu, Portugal, 2015.

\section{DISCUSSION}

First, we must mention that to have adopted strict selection criteria and rigidly followed every step of conducting a systematic review, we consider valid, reliable and transferable results. Yet we cannot help but notice that in some of the included studies researchers did not practice blinding, and yet there were some particular aspects of the allocation, randomization and incomplete data that were not met.

The heterogeneity found by statistical analysis is probably due to the difference between the methodological quality of the included RCT (methodological heterogeneity), the fact that they do not possess wholly similar interventions such as different dilutions of heparin solutions, the different types of CVC, and also because the populations have different pathology (clinical heterogeneity). We also acknowledge that the non-permeable definition of CVC is different between the included studies, which may possibly translate some level of statistical heterogeneity ${ }^{(11)}$. Nevertheless, by assuming the existence of these heterogeneities, by carrying out analyzes of subgroups and fulfilling all the recommendations, we believe that this fact does not limit our conclusions.

We therefore observed that heparin CVC has been considered over the years as a traditional and useful practice in maintaining the permeability of CVC, however this practice remains shrouded in some controversy. Heparin by itself is not a thrombolytic agent, it does not cause lysis or clot "fragmentation," but prevents the progression of previously existing clots by inhibiting the factors related to the process 
of clot formation, allowing lysis of the naturally occurring clot. Moreover, heparin has a very short lifespan (60 to 90 $\mathrm{min}$ ) and no data or evidence present perfect validity of the dilution and therapeutic components of CVC to meet the therapeutic effect on one hand, and on the other and even more critically do not produce its undesirable side effects ${ }^{(10)}$.

Moreover, there is no evidence in the literature that the concentration of heparin alone is related to improved permeable CVC rates, assuming a balance between effectiveness and safety of the patient ${ }^{(10)}$. However, the systemic effects of the use of heparin and the development of heparin-induced thrombocytopenia may constitute a problem ${ }^{(6)}$.

Despite the potential benefits of saline solution, the change in clinical practice for a normal saline solution has not been widely suggested in the literature for the whole typology of patients and CVC. A possible explanation for this may be attributed to the long period of time that CVC remains in the patient ${ }^{(25-27)}$, complications associated with maintaining $\mathrm{CVC}^{(28-31)}$, type of infusion used (medicinal, solutions... $)^{(32)}$; if the purpose of the CVC is hemodialysis $^{(9-14)}$ and institutional procedures for locking and flushing can strengthen medical belief about heparin effectiveness ${ }^{(10)}$, thus ultimately leading to exploiting the effectiveness of other solutions $^{(33)}$ (i.e. citrate).

Although most of the study's corpus suggest the use of saline solution, one study ${ }^{(6)}$ concluded that heparinized solutions are more effective when compared to saline solution for maintaining CVC patency. It is important to note that the flush technique has not been described in detail and it was performed only every 48 hours, which may have contributed to the differences, for example, in comparing this procedure to the study ${ }^{(11)}$ in which the flush technique has been described in detail and implemented every 8 hours. The same authors also point out that the strength of the results is due to adopting protocol operations and a higher nurse/patient ratio, so the standardization of practices for conducting a flush every 8 hours, and the criteria for the administrative flush order according to the intravenous therapy (treatments) and interventions are shown as vital procedures.

In defense of the determined evidence, it is also noteworthy that our meta-analysis results indicate that there is no statistically significant difference between the efficacies of flush solutions, which is supported by the value of meta-analytic results ( $\mathrm{RR}=0.68$, CI 95\%=0.41-1.10; $p=0.12)$. These results clearly show that implementing the saline solution flush in maintaining patency of CVC must be transferred to clinical practice.

In short, we should mention that the consensus among various authors and our results are consistent, allowing us to draw the following conclusions: the saline solution is sufficient for maintaining patency of CVC when compared to heparinized solutions ${ }^{(2,9-14,16)}$; saline solution prevents exposure to complications arising from the use of heparin - these being thrombocytopenia, bleeding ${ }^{(11,12,14,16)} \ldots$ thereby adding significance when associated with differences in the dilutions used (often by the team itself), non-uniformity of pre-established protocols and potential errors of medication preparation ${ }^{(1)}$.

\section{CONCLUSION}

Currently, CVC obstruction is assumed as an important concern for health professionals because it implies the suspension of therapies, an increase risk to the patient and associated costs. In this sense, strategies to reduce this complication are crucial, in particular the choice of solution being used to maintain CVC patency.

According to available evidence, the consensus among several authors and the results of this systematic review show no significant differences between the effectiveness of heparinized solutions and saline $0.9 \%$ in maintaining $\mathrm{CVC}$ patency in adults $(\mathrm{RR}=0.68, \mathrm{CI} 95 \%=0.41-1.10 ; p=0.12)$.

Considering that there is evidence that using saline solution is sufficient for maintaining CVC patency, thus preventing the risks associated with the administration of heparin, we suggest the realization and implementation of a new guideline; with the main purpose being better resource management, making the technique related to the issue of general research for all health professionals.

\section{Practical Implications}

The interventions considered in this systematic review are effective and can be useful in practice (Level of Evidence 1.b); health care professionals can use these interventions on adults (Grade A recommendation).

\section{ReSEARCH IMPLICATIONS}

It is necessary to properly carry out RCT designed to compare the clinical benefits, economic evaluations, patient safety and cost-effectiveness of solutions in different groups of patients (comorbidities), different types of CVC, CVC insertion reasons (intravenous therapy, parenteral nutrition, chemotherapy ...), according to the estimated time (short or long term) and covering other outcomes for establishing causal relationships (in addition to the number of nonpermeable CVC).

RCT that validate the application of a performance protocol are necessary to maintain CVC permeability by using $0.9 \%$ saline flush and that prove the effectiveness of different techniques.

\section{RESUMO}

Objetivo: Determinar qual é a solução (flush heparina comparado com o flush de soro fisiológico 0.9\%) mais eficaz na redução do risco de oclusões de cateteres venosos centrais (CVC) em adultos. Método: A revisão sistemática seguiu os princípios propostos pelo Cochrane Handbook; a análise crítica, a extração e a síntese dos dados foram realizadas por dois investigadores, isoladamente; e a análise estatística efetuada com recurso ao programa RevMan 5.2.8. Resultados: Foram incluídos oito estudos randomizados controlados e um estudo de 
coorte e os resultados da meta-análise mostram não existir diferenças ( $R R=0.68, \mathrm{IC} 95 \%=0.41-1.10$; $p=0.12)$. A análise por subgrupos mostra que nos CVC totalmente implantados não se verificaram diferenças ( $R R=1.09, \mathrm{IC} 95 \%=0.53-2.22 ; p=0.82)$; nos $\mathrm{CVC}$ com vários lúmens existiu um efeito benéfico no grupo da heparina $(\mathrm{RR}=0.53$, IC 95\%=0.29-0.95; $p=0.03)$; nos $\mathrm{CVC}$ de duplo lúmen para hemodiálise $(\mathrm{RR}=1.18$, IC 95\%=0.08-17.82; $p=0.90)$ e nos $\mathrm{CVC}$ de inserção periférica $(\mathrm{RR}=0.14, \mathrm{IC} 95 \%=0.01-2.60 ; p=0.19)$ também não se verificaram diferenças. Conclusão: $\mathrm{O}$ soro fisiológico é suficiente para manter a permeabilidade dos cateteres venosos centrais, prevenindo os riscos associados à administração da heparina.

\section{DESCRITORES}

Cateterismo Venoso Central; Heparina; Cloreto de Sódio; Cateteres Venosos Centrais; Revisão.

\section{RESUMEN}

Objetivo: Determinar cuál es la solución (fush con heparina comparado con el de suero fisiológico al 0,9\%) más eficaz en la reducción del riesgo de oclusiones de catéteres venosos centrales (CVC) en adultos. Método: La revisión sistemática siguió los principios propuestos por el Cocbrane Handbook; el análisis crítico, la extracción y la síntesis de los datos fueron realizados por dos investigadores, aisladamente; y el análisis estadístico fue llevado a cabo con recurso al programa RevMan 5.2.8. Resultados: Se incluyeron ocho estudios randomizados controlados y un estudio de cohorte, y los resultados del metaanálisis muestran no existir diferencias $(\mathrm{RR}=0.68$, IC 95\%=0.41-1.10; $p=0.12$ ). El análisis por subgrupos muestra que en los CVC totalmente implantados no se verificaron diferencias $(\mathrm{RR}=1.09, \mathrm{IC} 95 \%=0.53-2.22 ; p=0.82)$; en los $\mathrm{CVC}$ con varios lúmenes existió un efecto benéfico en el grupo de la heparina $(\mathrm{RR}=0.53$, IC 95\%=0.29-0.95; $p=0.03$ ); en los CVC de doble lumen para hemodiálisis ( $R R=1.18$, IC 95\%=0.08-17.82; $p=0.90)$ y en los CVC de inserción periférica $(\mathrm{RR}=0.14$, IC 95\%=0.01-2.60; $p=0.19)$ tampoco se verificaron diferencias. Conclusión: El suero fisiológico es suficiente para mantener la permeabilidad de los catéteres venosos centrales, previniendo los riesgos asociados con la administración de la heparina.

\section{DESCRIPTORES}

Cateterismo Venoso Central; Heparina; Cloruro de Sodio; Catéteres Venosos Centrales; Revisión.

\section{REFERENCES}

1. Encarnação RMC, Marques P. Permeabilidade do cateter venoso central: uma revisão sistemática da literatura. Rev Enf Ref. 2013; $\operatorname{serIII(9):161-9.~}$

2. Fuentes i Pumarola C, Casademont Mercader R, Colomer Plana M, Cordón Bueno C, Sabench Casellas S, Félez Vidal M, et al. Estudio comparativo del mantenimiento de la permeabilidad de los catéteres venosos centrales de tres luces. Enferm Intensiva. 2007; 18(1):25-35.

3. Dal Molin A, Allara E, Montani D, Milani S, Frassati C, Cossu S, et al. Flushing the central venous catheter: is heparin necessary? J Vasc Access. 2014;15(4):241-8.

4. Khanna V, Mukhopadhayay C, Verma VKE, Dabke P. Evaluation of central venous catheter associated blood stream infections: a microbiological observational study. J Pathog. 2013;2013:936864.

5. Registered Nurses' Association of Ontario. Care and maintenance to reduce vascular access complications: guideline supplement. Toronto: RNAO; 2008.

6. Rabe C, Gramann T, Sons X, Berna M, González-Carmona MA, Klehr HU, et al. Keeping central venous lines open: a prospective comparison of heparin, vitamin C and sodium chloride sealing solutions in medical patients. Intensive Care Med. 2002;28(8):1172-6.

7. Udeh Cl, Douglas A, Udeh BL, Hata JS. Heparin-induced thrombocytopenia: a clinical and economic review. OA Anaesthetics. $2013 ; 1(1): 3$.

8. Lee GM, Arepally GM. Heparin-induced thrombocytopenia. Hematology Am Soc Hematol Educ Program. 2013; 2013:668-74.

9. Kaneko Y, Iwano M, Yoshida H, Kosuge M, Ito S, Narita I, et al. Natural saline-flush is sufficient to maintain patency of immobilizedurokinase double-lumen catheter used to provide temporary blood access for hemodialysis. Blood Purif. 2004;22(5):473-9.

10. Bertoglio S, Solari N, Meszaros P, Vassallo F, Bonvento M, Pastorino S, et al. Efficacy of normal saline versus heparinized saline solution for locking catheters of totally implantable long-term central vascular access devices in adult cancer patients. Cancer Nurs. 2012;35(4):E35-42.

11. Schallom ME, Prentice D, Sona C, Micek ST, Skrupky LP. Heparin or 0.9\% sodium chloride to maintain central venous catheter patency: a randomized trial. Crit Care Med. 2012;40(6):1820-6.

12. Goossens GA, Jérôme M, Janssens C, Peetermans WE, Fieuws S, Moons $P$, et al. Comparing normal saline versus diluted heparin to lock non-valved totally implantable venous access devices in cancer patients: a randomised, non-inferiority, open trial. Ann Oncol. 2013;24(7):1892-9.

13. Bowers L, Speroni KG, Jones L, Atherton M. Comparison of occlusion rates by flushing solutions for peripherally inserted central catheters with positive pressure Lueractivated devices. J Infus Nurs. 2008;31(1):22-7.

14. Beigi AA, HadiZadeh MS, Salimi F, Ghaheri H. Heparin compared with normal saline to maintain patency of permanent double lumen hemodialysis catheters: a randomized controlled trial. Adv Biomed Res. 2014;3:121.

15. Sona C, Prentice D, Schallom L. National survey of central venous catheter flushing in the intensive care unit. Crit Care Nurse. 2012;32(1):e12-9.

16. Heidari Gorji MA, Rezaei F, Jafari H, Yazdani Cherati J. Comparison of the effects of heparin and $0.9 \%$ sodium chloride solutions in maintenance of patency of central venous catheters. Anesth Pain Med. 2015;5(2):e22595.

17. Higgins JPT, Green S. Cochrane Handbook for Systematic Reviews of Interventions. Version 5.1.0. [Internet]. London: The Cochrane Collaboration; 2011 [cited 2014 Oct 12]. Available from: http://www.cochrane-handbook.org 
18. Moher D, Liberati A, Tetzlaff J, Altman DG. Preferred reporting items for systematic reviews and meta-analyses: the PRISMA statement. Ann Intern Med. 2009;151(4):264-9, w64.

19. Liberati A, Altman DG, Tetzlaff J, Mulrow C, Gotzsche PC, loannidis JP, et al. The PRISMA statement for reporting systematic reviews and meta-analyses of studies that evaluate health care interventions: explanation and elaboration. PLoS Med. 2009;6(7):e1000100.

20. Carneiro A. Como avaliar a investigação clínica: o exemplo da avaliação crítica de um ensaio clínico. J Port Gastrenterol. 2008;15(1):30-6.

21. The Joanna Briggs Institute. User manual. Version 5.0 System for the Unified Management, Assessment and Review of Information. Adelaide: JBl; 2012.

22. The Joanna Briggs Institute. Reviewers' manual: 2014 edition. Adelaide: JBI; 2014.

23. Santos E, Cunha M. interpretação crítica dos resultados estatísticos de uma meta-análise: estratégias metodológicas. Millenium. 2013;44:85-98.

24. The Joanna Briggs Institute. The JBI Approach: levels of evidence and grades of recommendation. Adelaide: JBI; 2013.

25. Ferreira MVF, Andrade D, Ferreira AM. Infection control related to central venous catheter impregnated with antiseptics: an integrative review. Rev Esc Enferm USP [Internet]. 2011 [cited 2014 Oct 12];45(4):1002-6. Available from: http://www.scielo.br/pdf/reeusp/v45n4/ en_v45n4a30.pdf

26. Gomes AV, Nascimento MA. Central venous catheterization in pediatric and neonatal intensive care units. Rev Esc Enferm USP [Internet]. 2013 [cited 2014 Oct 12];47(4):794-800. Available from: http://www.scielo.br/pdf/reeusp/v47n4/en_0080-6234-reeusp-47-4-0794.pdf

27. Smith RN, Nolan JP. Central venous catheters. BMJ. 2013;347:f6570.

28. Chopra V, Anand S, Hickner A, Buist M, Rogers MA, Saint S, et al. Risk of venous thromboembolism associated with peripherally inserted central catheter: a systematic review and meta-analysis. Lancet. 2013;382(9889):311-25.

29. Napalkov P, Felici DM, Chu LK, Jacobs JR, Begelman SM. Incidence of catheter-related complications in patients with central venous or hemodialysis catheters: a health care claims database analysis. BMC Cardiovasc Disord. 2013;13:86.

30. Hammarskjöld F, Berg S, Hanberger H, Taxbro K, Malmvall BE. Sustained low incidence of central venous catheter-related infections over six years in a Swedish hospital with an active central venous catheter team. Am J Infect Control. 2014;42(2):122-8.

31. Silva TN, Marchi D, Mendes ML, Barretti P, Ponce D. Approach to prophylactic measures for central venous catheterrelated infections in hemodialysis: a critical review. Hemodial Int. 2014;18(1):15-23.

32. Moore CL, Besarab A, Ajluni M, Soi V, Peterson EL, Johnson LE, et al. Comparative effectiveness of two catheter locking solutions to reduce catheter-related bloodstream infection in hemodialysis patients. Clin J Am Soc Nephrol. 2014;9(7):1232-9.

33. Boersma RS, Jie KS, Voogd AC, Hamulyak K, Verbon A, Schouten HC. Concentrated citrate locking in order to reduce the long-term complications of central venous catheters: a randomized controlled trial in patients with hematological malignancies. Support Care Cancer. 2015;23(1):37-45. 